\title{
Single nucleotide polymorphisms in the regulatory region of gonadotropin-releasing hormone receptor gene and breast cancer susceptibility
}

\author{
CLAUS LATTRICH, ANNA-KRISTIN MÜLLER, SUSANNE SCHÜLER, \\ JULIA HÄRING, ALEXANDRA RUOFF, OLIVER TREECK and OLAF ORTMANN \\ Department of Obstetrics and Gynecology, University Medical Center Regensburg, D-93057 Regensburg, Germany
}

Received February 17, 2012; Accepted May 11, 2012

DOI: $10.3892 /$ or.2012.1854

\begin{abstract}
It is known that exposure to estrogens affects the pathophysiology of breast cancer. The key role of gonadotropin-releasing hormone $(\mathrm{GnRH})$ in the regulation of female steroid hormone metabolism raises the question of whether polymorphisms in its receptor, GnRHR, might influence breast cancer risk. To test this hypothesis, we analyzed three single nucleotide polymorphisms (SNPs) in the 5'-regulatory region of the GnRHR gene in a total of 565 women, 254 women with breast cancer and 311 women without any malignancy by allele-specific PCR. No significant differences were observed between the breast cancer and control group in terms of genotype, allele frequency or allele positivity. In contrast, different frequencies of the SNPs rs13138607, rs12644822 and rs3756159 were observed after sub-grouping the breast cancer cases according to tumor grading. Our data suggest a potential role of GnRHR gene polymorphisms in the development of breast cancer.
\end{abstract}

\section{Introduction}

Gonadotropin-releasing hormone $(\mathrm{GnRH})$ as a part of the hypothalamic-pituitary-gonadal axis is the key hormone in the control of reproductive functions. It induces the release of gonadotropines, follicle-stimulating hormone (FSH) and luteinizing hormone ( $\mathrm{LH})$, from the anterior pituitary gland. These hormones have stimulating effects on the gonades resulting in an increased production of estrogens, gestagens and androgens. GnRH acts by binding to its specific highaffinity receptor localized on the gonadotrope cells. The $\mathrm{GnRH}$ receptor, which belongs to the family of 7TM domain receptors, regulates gene expression through G-protein coupled

Correspondence to: Dr Oliver Treeck, Department of Obstetrics and Gynecology, University Medical Center Regensburg, D-93057 Regensburg, Germany

E-mail: otreeck@caritasstjosef.de

Key words: breast cancer, gonadotropin-releasing hormone gene, single nucleotide polymorphisms signal cascades, involving phospholipases and adenylate cyclase (1-3).

Given that estrogen exposure is a known risk factor for breast cancer, the examination of genetic variants in genes encoding for proteins of steroid hormone metabolism regulation attracted high attention (4-8). Genetic variations of GnRHR gene, which might affect GnRH receptor levels or the structure of this receptor, could influence the disease rate or cancer progression by differential regulation of steroid hormone synthesis. Besides this hypothesis of indirect effects on tumor progress via steroide hormones, a direct effect by extrapituitary GnRHR receptor signaling in gynecological cancer cells has been shown $(9,10)$. The majority of human breast cancers express GnRHR and evidence is growing for an estrogen-independent intrinsic regulation of breast cancer cell proliferation mediated by GnRHR (11). Thus, GnRHR has been suggested to be an interesting therapeutic target for breast cancer therapy (12-16).

In this phenotype-genotype association study, we tested whether three SNPs in the GnRHR gene might be associated with breast cancer risk or with histopathological characteristics of the tumor. For this purpose, we genotyped 565 DNA samples from women with or without breast cancer and analyzed the genotype frequency, allele frequency and allele positivity in both groups and in histopathological sub-groups.

\section{Patients and methods}

Patients. Blood samples from 254 Caucasian women with sporadic breast cancer and 311 age-matched Caucasian women without any malignancy were included in this retrospective study. The histopathological characteristics of the patients are shown in Table I. Whole blood or DNA samples of breast cancer case participants were provided by the Institute of Pathology, University of Regensburg, in an anonymous and randomized manner or have been collected at the department of Obstetrics and Gynecology, University of Regensburg, between 2005 and 2007. Control subjects were selected from the same geographic origin as the cases, the Oberpfalz area of Bavaria, Germany. Inclusion criterion for the control subjects was the absence of any clinical relevant malignancy at the beginning of the study. The study was approved by the Ethics 
Table I. Histopathological characteristics and receptor status of breast cancer cases included in this study $(n=254)$.

\begin{tabular}{|c|c|}
\hline Characteristic & Patient (n) \\
\hline \multicolumn{2}{|l|}{ Tumor size } \\
\hline pT1 & 146 \\
\hline pT2 & 86 \\
\hline pT3 & 8 \\
\hline pT4 & 10 \\
\hline $\mathrm{pT}^{\mathrm{a}}$ & 4 \\
\hline \multicolumn{2}{|c|}{ Histological grade } \\
\hline G1 & 31 \\
\hline G2 & 137 \\
\hline G3 & 83 \\
\hline $\mathrm{G}^{\mathrm{a}}$ & 3 \\
\hline \multicolumn{2}{|l|}{ Nodal status } \\
\hline No & 156 \\
\hline $\mathrm{N} 1-3$ & 82 \\
\hline $\mathrm{N}^{\mathrm{a}}$ & 16 \\
\hline \multicolumn{2}{|l|}{ ER $\alpha$ status } \\
\hline Negative & 40 \\
\hline Positive & 204 \\
\hline Intermediate ${ }^{\mathrm{b}}$ & 7 \\
\hline $\mathrm{ER}^{\mathrm{a}}$ & 3 \\
\hline \multicolumn{2}{|l|}{ PR status } \\
\hline Negative & 83 \\
\hline Positive & 149 \\
\hline Intermediate $^{\mathrm{b}}$ & 20 \\
\hline $\mathrm{PR}^{\mathrm{a}}$ & 2 \\
\hline \multicolumn{2}{|l|}{ Her2 status } \\
\hline Negative & 195 \\
\hline Positive & 41 \\
\hline Her $2^{a}$ & 18 \\
\hline
\end{tabular}

${ }^{\text {a }}$ Samples not specified in the respective category. ${ }^{\mathrm{b}}$ Samples tested low-positive; not included in the statistics. The median age of patients was 55.6 years (range, 24-82 years).

Committee of the University of Regensburg and informed consent of the patients was collected.

SNP analysis. Three SNPs in the GnRHR gene were identified using the web sites www.genecards.org and http://www. ncbi.nlm.nih.gov/SNP. The basis of SNP selection was their possible biological relevance. All chosen SNPs are located in regulatory regions of GnRHR gene. The polymorphism rs13138607 is located at position 68304145 on chromosome 4 in the 5 ' untranslated region of GnRHR gene, in an exonic splicing enhancer binding site (Fig. 1). SNP rs12644822 at position 68305130 is located in the 5 ' region near the GnRHR gene. Polymorphism rs3756159 at position 68305073 also located in the 5 ' region near the gene is part of a transcription factor binding site. Reported HapMap genotype frequencies for SNP rs13138607, from the web site http://www.ncbi.nlm.
nih.gov/SNP, were 0.298 (T/T), $0.351(\mathrm{C} / \mathrm{C})$ and $0.351(\mathrm{~T} / \mathrm{C})$, in a population of 114 individuals from UT, USA with ancestors in Western and Northern Europe (CEU). Published frequencies for rs12644822 were $0.217(\mathrm{~T} / \mathrm{T}), 0.450(\mathrm{C} / \mathrm{C})$ and 0.333 (T/C) in the HapMap CEU population, and 0.288 (T/T), 0.339 $(\mathrm{C} / \mathrm{C})$ and $0.373(\mathrm{~T} / \mathrm{C})$ for SNP rs3756159 in the same population.

Genomic DNA was extracted from $100 \mu 1$ EDTA-blood after addition of $300 \mu \mathrm{l}$ lysis buffer [ $1 \% \mathrm{v} / \mathrm{v}$ Triton-X, $0.32 \mathrm{M}$ Sucrose, 0.01M Tris ( $\mathrm{pH} 7.5$ ) and $5 \mathrm{mM} \mathrm{MgCl}_{2}$ ) and 2-fold centrifugation $(13,000 \mathrm{x}$ g] for $30 \mathrm{sec}$. Pellet was resuspended in $50 \mu 1$ PCR buffer (GoTaq buffer, Promega, Madison, WI, USA) containing $0.5 \%$ Tween-20 and 10 mAnson units proteinase $\mathrm{K}$ (Merck, Darmstadt, Germany) followed by incubation at $50^{\circ} \mathrm{C}$ overnight and finally heat inactivation of the enzyme for $10 \mathrm{~min}$ at $95^{\circ} \mathrm{C}$. The genomic DNA-containing lysate was subjected to a tetra-primer ARMS PCR approach (17) allowing allele-specific amplification using the PCR primers listed in Table II (synthesized at Metabion, Martinsried, Germany). For this purpose, to $100 \mathrm{ng}$ of genomic DNA, $2 \mu \mathrm{l}$ of 5X GoTaq buffer, $0.2 \mu$ l of dNTP Mix (10 mM) (Fermentas, St. Leon-Rot, Germany), $0.2 \mu \mathrm{l}$ of each PCR primer $(10 \mu \mathrm{M})$ and 0.5 units GoTaq polymerase (Promega) were added and PCR reaction was carried out using a T1 thermocycler (Biometra, Göttingen, Germany). The PCR program for SNP analysis was $10 \mathrm{~min}$ $94^{\circ} \mathrm{C}$ followed by $38 \mathrm{PCR}$ cycles (rs13138607 and rs3756159) respectively 37 cycles (rs12644822) of $94^{\circ} \mathrm{C}(30 \mathrm{sec}), 60^{\circ} \mathrm{C}$ (30 sec) and $72^{\circ} \mathrm{C}(60 \mathrm{sec})$, followed by a final extension for 5 min step at $72^{\circ} \mathrm{C}$. PCR products were analyzed by $1.5 \%$ agarose gel electrophoresis. Allele-specific PCR product sizes for SNP rs13138607 were 187/248 bp (C/T), 197/263 bp (C/T) for rs12644822 and 112/149 bp (C/T) for SNP rs3756159. As a control for genotyping in each PCR run three previously characterized samples representing the heterozygous and the two homozygous genotypes in addition to the unknown samples were analyzed.

Statistical analysis. Hardy-Weinberg equilibrium was estimated by the Fisher's exact test and the $\chi^{2}$ test, and all values were subjected to one-way ANOVA to achieve homogeneity of variance. Statistical tests for association $(95 \% \mathrm{CI}$, confidence interval) and for significance were carried out using SPSS for Windows 8.0 (SPSS, Inc., Chicago, IL, USA). Afterwards tests for deviation from Hardy-Weinberg equilibrium were conducted, allele frequency, allele positivity and genotype frequencies were determined. Odds ratio (OR) was calculated using the more frequent homozygous genotypes as reference group.

\section{Results}

Although neither analysis of genotype and allele frequency nor of allele positivity of GnRHR SNPS rs13138607, rs3756159 and rs12644822 revealed significant differences between the cancer and the control group (Table III), we observed differences in SNP frequencies after sub-grouping the breast cancer cases with regard to their tumor grading.

Homozygous analysis of SNP rs13138607, located in an exonic splicing enhancer binding site of GnRHR gene, demonstrated that the $\mathrm{CC}$ genotype was less frequent in patients 


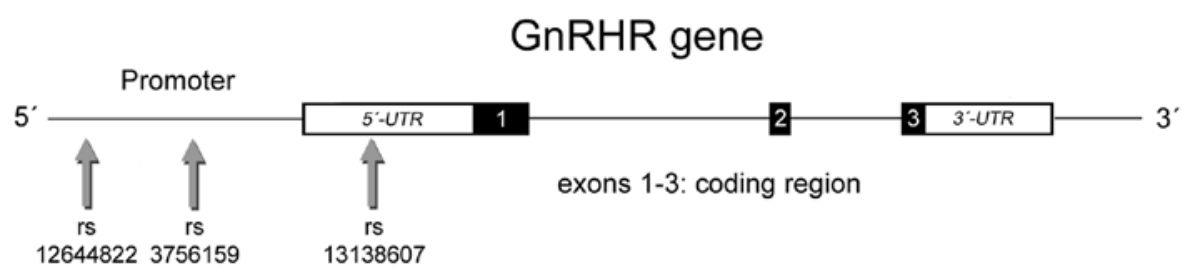

Figure 1. Localization of the three SNPs genotyped in this study in the GnRHR gene. Black boxes, GnRHR exons; UTR, untranslated region.

Table II. Oligonucleotides used for SNP genotyping by means of tetra primer PCR.

\begin{tabular}{lll}
\hline SNP & Primer & \\
\hline rs12644822 & $822-\mathrm{T}$ & Sequence $\left(5^{\prime} \rightarrow 3^{\prime}\right)$ \\
& $822-\mathrm{C}$ & AAGTAGAGGGCGAATGATGTTTGCCA \\
& $822-1$ & ATTCAACAACTTAGAGCTCCTCAAAGGC \\
rs3756159 & $822-2$ & TGTCTCTGCTTCACCTTCCTCAACCATA \\
& $159-\mathrm{T}$ & AGAATGCCTTGAAGGGATTTGGGAAATA \\
& $159-\mathrm{C}$ & CCGACTTTCATAGCCACACCCTGAAT \\
rs13138607 & $159-1$ & CACAACATGAAAGGTATAAAGCCCTCCAG \\
& $159-2$ & TTCAACAACTTAGAGCTCCTCAAATGCG \\
& $607-\mathrm{T}$ & TGTAGCATACAGAGAATGCCTTGAAGGG \\
& $607-\mathrm{C}$ & TTGTGACCATAAAATTTTACCTCCA \\
& $607-1$ & TTCTCCTAGATGAGTCAGAACTTAGTTTTTAC \\
& $607-2$ & TATTTGTATGTCTTTCCAATGGTTATCC \\
& CTGAGCTCCTTTTTGACTGTCACTATAT
\end{tabular}

The PCR product sizes (bp) were for rs12644822, T allele, 263; C allele, 197; and outer primers, 405; for rs3756159, T allele, 196; A allele, 231; and outer primers, 385; for rs 1313860, T allele, 198; T allele, 237; and outer primers, 391.

Table III. Analysis of GnRHR SNP frequencies in breast cancer cases and controls (healthy women).

\begin{tabular}{|c|c|c|c|c|c|c|c|}
\hline & \multicolumn{3}{|c|}{ Genotype frequency } & \multicolumn{2}{|c|}{ Allele frequency } & \multicolumn{2}{|c|}{ Allele positivity } \\
\hline & $\mathrm{CC}$ & $\mathrm{TT}$ & $\mathrm{CT}$ & $\mathrm{C}$ & $\mathrm{T}$ & $\mathrm{C}$ & $\mathrm{T}$ \\
\hline \multicolumn{8}{|l|}{ SNP rs12644822 } \\
\hline Cases $(n=240)$ & 0.35 & 0.12 & 0.54 & 0.61 & 0.39 & 0.88 & 0.65 \\
\hline Controls $(n=243)$ & 0.36 & 0.14 & 0.50 & 0.61 & 0.39 & 0.86 & 0.64 \\
\hline P-value & & 0.621 & 0.605 & & 0.860 & & 0.443 \\
\hline \multicolumn{8}{|l|}{ SNP rs3756159 } \\
\hline Cases $(n=241)$ & 0.21 & 0.20 & 0.59 & 0.50 & 0.50 & 0.80 & 0.79 \\
\hline Controls $(n=244)$ & 0.26 & 0.24 & 0.50 & 0.51 & 0.49 & 0.76 & 0.74 \\
\hline P-value & & 0.878 & 0.140 & & 0.773 & & 0.305 \\
\hline \multicolumn{8}{|l|}{ SNP rs13138607 } \\
\hline Cases $(n=238$ & 0.24 & 0.24 & 0.52 & 0.50 & 0.50 & 0.76 & 0.76 \\
\hline Controls $(n=243)$ & 0.26 & 0.23 & 0.51 & 0.52 & 0.48 & 0.77 & 0.74 \\
\hline P-value & & 0.652 & 0.820 & & 0.663 & & 0.694 \\
\hline
\end{tabular}

After tests for deviation from Hardy-Weinberg equilibrium were conducted, allele frequency, allele positivity and genotype frequencies were determined. $\mathrm{n}$, the total number of samples in each category.

with poorly differentiated (G3) tumors (18\%) than in patients with better differentiated (G1 and G2) tumors (27\%, OR,
$2.65, \mathrm{P}=0.017)$ or in healthy women $(26 \%, \mathrm{OR}, 2.03, \mathrm{P}=0.04)$ (Table IV). Analysis of allele frequency and allele positivity 
Table IV. Subgroup analysis of GnRHR SNP frequencies.

\begin{tabular}{|c|c|c|c|c|c|c|c|}
\hline & \multicolumn{3}{|c|}{ Genotype frequency } & \multicolumn{2}{|c|}{ Allele frequency } & \multicolumn{2}{|c|}{ Allele positivity } \\
\hline & $\mathrm{CC}$ & TT & CT & $\mathrm{C}$ & $\mathrm{T}$ & $\mathrm{C}$ & $\mathrm{T}$ \\
\hline \multicolumn{8}{|l|}{ SNP rs12644822 } \\
\hline $\mathrm{G} 1+2(\mathrm{n}=163)$ & 0.29 & 0.13 & 0.58 & 0.58 & 0.42 & 0.87 & 0.71 \\
\hline G3 $(n=74)$ & 0.46 & 0.09 & 0.45 & 0.68 & 0.32 & 0.91 & 0.54 \\
\hline P-value & & 0.120 & 0.019 & & 0.039 & & 0.013 \\
\hline OR & & & 2.018 & & 1.538 & & 2.037 \\
\hline $95 \% \mathrm{CI}$ & & & $1.12-3.65$ & & $1.02-2.32$ & & $0.28-0.87$ \\
\hline \multicolumn{8}{|l|}{ SNP rs3756159 } \\
\hline $\mathrm{G} 1+2(\mathrm{n}=161)$ & 0.23 & 0.16 & 0.61 & 0.53 & 0.47 & 0.84 & 0.77 \\
\hline Controls $(\mathrm{n}=311)$ & 0.23 & 0.26 & 0.51 & 0.49 & 0.51 & 0.74 & 0.74 \\
\hline P-value & & 0.1293 & 0.447 & & 0.1707 & 0.0324 & 0.9669 \\
\hline OR & & & & & & 1.682 & \\
\hline $95 \% \mathrm{CI}$ & & & & & & $0.34-0.91$ & \\
\hline \multicolumn{8}{|l|}{ SNP rs13138607 } \\
\hline G3 $(n=74)$ & 0.18 & 0.34 & 0.49 & 0.42 & 0.58 & 0.66 & 0.82 \\
\hline Controls (n=311) & 0.26 & 0.23 & 0.51 & 0.52 & 0.48 & 0.77 & 0.74 \\
\hline P-value & & 0.04 & 0.3511 & & 0.038 & 0.053 & 0.1403 \\
\hline OR & & 2.03 & & & 1.482 & & \\
\hline $95 \% \mathrm{CI}$ & & $1.03-4.72$ & & & $1.02-2.15$ & & \\
\hline $\mathrm{G} 1+2(\mathrm{n}=161)$ & 0.27 & 0.20 & 0.53 & 0.54 & 0.46 & 0.80 & 0.73 \\
\hline G3 $(n=74)$ & 0.18 & 0.34 & 0.49 & 0.42 & 0.58 & 0.66 & 0.82 \\
\hline P-value & & 0.017 & 0.333 & & 0.017 & 0.021 & 0.1048 \\
\hline OR & & 2.65 & & & 1.61 & 2.05 & \\
\hline $95 \%$ CI & & $0.17-0.85$ & & & $0.42-0.92$ & $0.26-0.90$ & \\
\hline
\end{tabular}

After tests for deviation from Hardy-Weinberg equilibrium were conducted, allele frequency, allele positivity and genotype frequencies were determined. Odds ratio (OR) was calculated using the more frequent homozygous genotypes as reference group. $\mathrm{G}$, tumor grading; $\mathrm{n}$ is the total number of samples in each category. Bold, statistically significant.

of this SNP also showed the $\mathrm{C}$ allele to be less frequent in $\mathrm{G} 3$ tumors than in G1 and G2 tumors (frequency 42 vs. 54\%, OR, $1.61, \mathrm{P}=0.017$, positivity 66 vs. $80 \%, \mathrm{OR}, 2.05, \mathrm{P}=0.021)$ and than in healthy women (OR, 1.48, $\mathrm{P}=0.038)$.

Comparing the grading subgroups for SNP rs3756159, we found the C-allele positivity to be increased in the $\mathrm{G} 1+\mathrm{G} 2$ group when compared to the group of women without any malignancy (OR, 1.682, $\mathrm{P}=0.324)$.

Examining SNP rs12644822, a higher incidence of homozygote CC vs. the heterozygote genotype was found in poorly differentiated tumors (G3) in comparison to well or moderately differentiated tumors (G1 and G2) $(\mathrm{OR}, 2.018, \mathrm{P}=0.019)$. Additionally, both T-allele frequency and T-allele positivity of SNP rs12644822 were decreased in G3 tumors (Table III).

\section{Discussion}

Since discovery of common genetic variants such as singlenucleotide polymorphisms, genotype-phenotype association studies have explored their impact as susceptibility factors predisposing individuals to a variety of diseases. SNPs located in exon regions of a gene may alter protein structure and func- tion or may influence gene expression levels when localized in gene regulatory regions. In this study, we selected SNPs with a potential relevance for gene expression, located in an exonic splicing enhancer binding site or in the 5'-promoter region of GnRHR gene.

Significant association of common alleles with an etiologically complex disease like breast cancer was shown in numerous studies (18-21). SNPs in genes whose products are known to be involved in malign pathophysiological processes attracted the main attention. In hormone-dependent cancer such as breast cancer, particularly SNPs in genes involved in estrogen biosynthesis and signaling or hormones of the hypothalamic-pituitary-gonadal axis are of great interest (22). In previous SNP studies on GNRH receptor gene, certain polymorphisms have been found to be associated with polycystic ovary syndrome, but did not associate with idiopathic hypogonadotropic hypogonadism (23-26). With regard to breast cancer, recently an SNP in the GnRH gene was reported to be significantly associated with disease-free survival and negative nodal status of premenopausal breast cancer patients (27). In contrast, another large breast cancer study on SNPs in the GnRH and GnRHR gene could not find a statistically 
significant association with breast cancer risk (26). Only one previous study examined SNPs in the 5'-region of GnRHR gene, but did not associate it with breast cancer risk, but with onset of menarche (28).

To the best of our knowledge, this is the first study examining the relevance of three SNPs in the 5'-regulatory region of GnRHR for breast cancer susceptibility. In our population, the frequencies of the tested SNPs did not differ between women with breast cancer and the control collective, but we observed some differences between grading subgroups. However, due to the performed multiple comparison testing, the obtained P-values between 0.1 and 0.5 do not express statistical significance, but only reflect a trend towards significance. Thus, the results suggesting the T-allele of rs12644822 to be less frequent in G3 tumors, and C-allele positivity of rs3756159 to be increased in $\mathrm{G} 1$ and $\mathrm{G} 2$ tumors, needs to be confirmed on a larger patient collective. The same is true for the observations on frequency of SNP rs13138607, suggesting an association both of the TT genotype and of T allele with G3 tumors.

In conclusion, we did not observe an association between the tested SNPs in the 5'-regulatory region of GnRHR gene and breast cancer susceptibility. Our data demonstrating a statistical trend for association of GnRHR alleles with tumor grading might encourage further studies on larger study populations.

\section{References}

1. Chi L, Zhou W, Prikhozhan A, et al: Cloning and characterization of the human GnRH receptor. Mol Cell Endocrinol 91: R1-R6, 1993.

2. Lariviere S, Garrel G, Simon V, et al: Gonadotropin-releasing hormone couples to 3',5'-cyclic adenosine-5'-monophosphate pathway through novel protein kinase Cdelta and -epsilon in LbetaT2 gonadotrope cells. Endocrinology 148: 1099-1107, 2007.

3. Limonta P, Moretti RM, Marelli MM and Motta M: The biology of gonadotropin hormone-releasing hormone: role in the control of tumor growth and progression in humans. Front Neuroendocrinol 24: 279-295, 2003.

4. Lee E, Schumacher F, Lewinger JP, et al: The association of polymorphisms in hormone metabolism pathway genes, menopausal hormone therapy, and breast cancer risk: a nested case-control study in the California Teachers Study cohort. Breast Cancer Res 13: R37, 2011.

5. Udler MS, Azzato EM, Healey CS, et al: Common germline polymorphisms in COMT, CYP19A1, ESR1, PGR, SULT1E1 and STS and survival after a diagnosis of breast cancer. Int J Cancer 125: 2687-2696, 2009.

6. Zhang L, Gu L, Qian B, et al: Association of genetic polymorphisms of ER-alpha and the estradiol-synthesizing enzyme genes CYP17 and CYP19 with breast cancer risk in Chinese women. Breast Cancer Res Treat 114: 327-338, 2009.

7. Diergaarde B, Potter JD, Jupe ER, et al: Polymorphisms in genes involved in sex hormone metabolism, estrogen plus progestin hormone therapy use, and risk of postmenopausal breast cancer. Cancer Epidemiol Biomarkers Prev 17: 1751-1759, 2008.

8. Ralph DA, Zhao LP, Aston CE, et al: Age-specific association of steroid hormone pathway gene polymorphisms with breast cancer risk. Cancer 109: 1940-1948, 2007.

9. Emons G, Ortmann O, Becker M, et al: High affinity binding and direct antiproliferative effects of LHRH analogues in human ovarian cancer cell lines. Cancer Res 53: 5439-5446, 1993.

10. Emons G, Schroder B, Ortmann O, Westphalen S, Schulz KD and Schally AV: High affinity binding and direct antiproliferative effects of luteinizing hormone-releasing hormone analogs in human endometrial cancer cell lines. J Clin Endocrinol Metab 77: 1458-1464, 1993.
11. Cheung LW, Leung PC and Wong AS: Gonadotropin-releasing hormone promotes ovarian cancer cell invasiveness through c-Jun NH2-terminal kinase-mediated activation of matrix metalloproteinase (MMP)-2 and MMP-9. Cancer Res 66: 10902-10910, 2006.

12. Fost C, Duwe F, Hellriegel M, Schweyer S, Emons G and Grundker C: Targeted chemotherapy for triple-negative breast cancers via LHRH receptor. Oncol Rep 25: 1481-1487, 2011.

13. Schubert A, Hawighorst T, Emons G and Gründker C: Agonists and antagonists of GnRH-I and -II reduce metastasis formation by triple-negative human breast cancer cells in vivo. Breast Cancer Res Treat 130: 783-790, 2011.

14. Torrisi R, Bagnardi V, Rotmensz N, et al: Letrozole plus GnRH analogue as preoperative and adjuvant therapy in premenopausal women with ER positive locally advanced breast cancer. Breast Cancer Res Treat 126: 431-441, 2011.

15. Grundker C, Fost C, Fister S, Nolte N, Gunthert AR and Emons G: Gonadotropin-releasing hormone type II antagonist induces apoptosis in MCF-7 and triple-negative MDA-MB-231 human breast cancer cells in vitro and in vivo. Breast Cancer Res 12: R49, 2010.

16. Emons G, Kaufmann M, Gorchev G, et al: Dose escalation and pharmacokinetic study of AEZS-108 (AN-152), an LHRH agonist linked to doxorubicin, in women with LHRH receptorpositive tumors. Gynecol Oncol 119: 457-461, 2010.

17. Ye S, Dhillon S, Ke X, Collins AR and Day IN: An efficient procedure for genotyping single nucleotide polymorphisms. Nucleic Acids Res 29: E88-E88, 2001.

18. Harlid S, Ivarsson MI, Butt S, et al: Combined effect of lowpenetrant SNPs on breast cancer risk. Br J Cancer 106: 389-396, 2012.

19. Pelletier C, Speed WC, Paranjape T, et al: Rare BRCA1 haplotypes including 3'UTR SNPs associated with breast cancer risk. Cell Cycle 10: 90-99, 2011.

20. Han W, Kang SY, Kang D, et al: Multiplex genotyping of 1107 SNPs from 232 candidate genes identified an association between IL1A polymorphism and breast cancer risk. Oncol Rep 23: 763-769, 2010.

21. Hamacher R, Diersch S, Scheibel M, et al: Interleukin 1 beta gene promoter SNPs are associated with risk of pancreatic cancer. Cytokine 46: 182-186, 2009.

22. Park IH, Lee YS, Lee KS, et al: Single nucleotide polymorphisms of CYP19A1 predict clinical outcomes and adverse events associated with letrozole in patients with metastatic breast cancer. Cancer Chemother Pharmacol 68: 1263-1271, 2011.

23. Li Q, Yang G, Wang Y, et al: Common genetic variation in the 3'-untranslated region of gonadotropin-releasing hormone receptor regulates gene expression in cells and is associated with thyroid function, insulin secretion as well as insulin sensitivity in polycystic ovary syndrome patients. Hum Genet 129: 553-561, 2011.

24. Vagenakis GA, Sgourou A, Papachatzopoulou A, Kourounis G, Papavassiliou AG and Georgopoulos NA: The gonadotropinreleasing hormone (GnRH)-1 gene, the GnRH receptor gene, and their promoters in patients with idiopathic hypogonadotropic hypogonadism with or without resistance to GnRH action. Fertil Steril 84: 1762-1765, 2005.

25. Lanfranco F, Gromoll J, von Eckardstein S, Herding EM, Nieschlag E and Simoni M: Role of sequence variations of the $\mathrm{GnRH}$ receptor and $\mathrm{G}$ protein-coupled receptor 54 gene in male idiopathic hypogonadotropic hypogonadism. Eur J Endocrinol 153: 845-852, 2005.

26. Valkenburg O, Uitterlinden AG, Piersma D, et al: Genetic polymorphisms of $\mathrm{GnRH}$ and gonadotrophic hormone receptors affect the phenotype of polycystic ovary syndrome. Hum Reprod 24: 2014-2022, 2009.

27. Piersma D, Themmen AP, Look MP, et al: GnRH and LHR gene variants predict adverse outcome in premenopausal breast cancer patients. Breast Cancer Res 9: R51, 2007.

28. Nanao K and Hasegawa Y: Polymorphisms at the 5 ' end of the human gonadotropin-releasing hormone receptor gene are not associated with the timing of menarche in Japanese girls. Eur J Endocrinol 143: 555-556, 2000. 